\title{
Red Imported Fire Ant in Australia: What if we lose the war?
}

\author{
By F. Ross Wylie and Sharon Janssen-May
}

F. Ross Wylie is Science Manager and Sharon Janssen-May is Principal Policy Officer with the Queensland Department of Agriculture and Fisheries, Biosecurity Queensland Control Centre (55 Priors Pocket Rd, Moggill, Qld 4070, Australia; Tel: +6173330 4621; Email: ross.wylie@daf.qld.gov.au). This manuscript arose from a desire to emphasise some of the adverse impacts and costs that may occur if eradication of Red Imported Fire Ant is unsuccessful in Australia.
Summary In Australia, a national eradication programme for the Red Imported Fire Ant (Solenopsis invicta Buren), one of the world's most invasive species, has been in operation since 2001 when the pest was first detected in Brisbane, Queensland. Since that time, four separate incursions of this ant have been successfully eradicated from this country, but the main Brisbane population remains. Cost-benefit analyses already conducted put the likely impact of Red Imported Fire Ant in Australia, if not eradicated, at between A\$8.5 and A $\$ 45$ billion. Despite this, ongoing funding for the eradication programme is not assured. A recent external review has concluded that it remains technically feasible, cost beneficial and in the national interest to eradicate. In support of previous analyses, our study highlights some of the potential impacts of Red Imported Fire Ant in Australia in more detail and provides case examples. Results show that adverse impacts are likely in most sectors of the economy, and will be felt not only by agricultural industries, but also the building and construction, tourism, electrical and communications industries. In addition to industry effects, there will also be negative impacts on public health and lifestyle, the environment and infrastructure such as main roads, airports and schools. Our estimates of potential cost impacts in the case examples where extrapolation was possible exceed A\$1.65 billion/year and support previous predictions. We conclude that increased spending is justified to avert 'invasion debt' - the future cost of battling pests that escape today. This is a war that Australia cannot afford to lose.

Key words: agriculture, animals, environment, health, impact, infrastructure, lifestyle, Red Imported Fire Ant, Solenopsis invicta.

\section{Introduction}

ncreasing trade and commerce have led to the unintended transport of ants across the world, and McGlynn (1999) lists 147 species that have been recorded outside of their native habitat. Approximately 40 of these have widespread geographical distributions and are closely tied to urban areas and human activity; these are 'tramp' ants, a phrase used for the various ant species that travel the globe. A small subset of tramp ants are termed 'invasive ants' because they move into natural areas, disturbed or undisturbed, and outcompete native ants (Holway et al. 2002). One of the worst of these is the Red Imported Fire Ant, Solenopsis invicta Buren (Lowe et al. 2000).

Red Imported Fire Ant was first detected in Australia at two sites in Brisbane, Queensland, in 2001 (Moloney \& Vanderwoude 2002). A National Red Imported Fire Ant Eradication Programme (the programme) commenced in September that year and is ongoing. The programme has had some notable successes with the declared eradication of a genetically distinct population at the Port of Brisbane (8300 ha) in 2012 and another at Yarwun (71 ha) in central Queensland in 2010. These eradications, respectively, are the largest and third largest recorded for any ant species worldwide (Hoffmann et al. 2016; Wylie et al. 2016). In addition, eradication of two more recent incursions at the Port of Gladstone in Queensland in 2013 and Port Botany in New South Wales in 2014 have now been successfully completed. Efforts to eradicate the remaining 'Richlands' population in Brisbane continue. The current 'footprint' of this infestation, the area in which controls are applied on the movement of materials likely to harbour Red Imported Fire Ant, is approximately $400000 \mathrm{ha}$, but the actual area infested is only a small fraction of that and is very dispersed and generally low density. This in itself is a success story; it is estimated that in the absence of the eradication programme and if spread were to occur at the same rate as recorded in Texas in the USA - $48 \mathrm{~km}$ each year between 1957 and 1977 (Hung \& Vinson 1978) - then Red Imported Fire Ant would now be found south almost to Sydney, north to Mackay and west of Charleville in Queensland (Biosecurity Queensland Control Centre (BQCC) unpublished data). This represents an area of about 69 million ha (Fig. 1). In China, the ant has spread even more quickly, at an estimated rate of $80 \mathrm{~km}$ per year (Lu et al. 2008). Barr (2002) notes that mound density of 506 mounds/ha is fairly typical in central Texas, but in Queensland, such densities are a rare occurrence since the advent of the programme.

However, in 2016 the programme is at a crossroads. A total of A $\$ 330$ million has been spent over 15 years. Findings of a recent external review of the programme are that it is still in the interests of Australia to eradicate Red Imported Fire Ant and that it is still technically feasible but questions remain about strategies and costs.

Three cost-benefit analyses put the likely impact in Australia, if the ant 


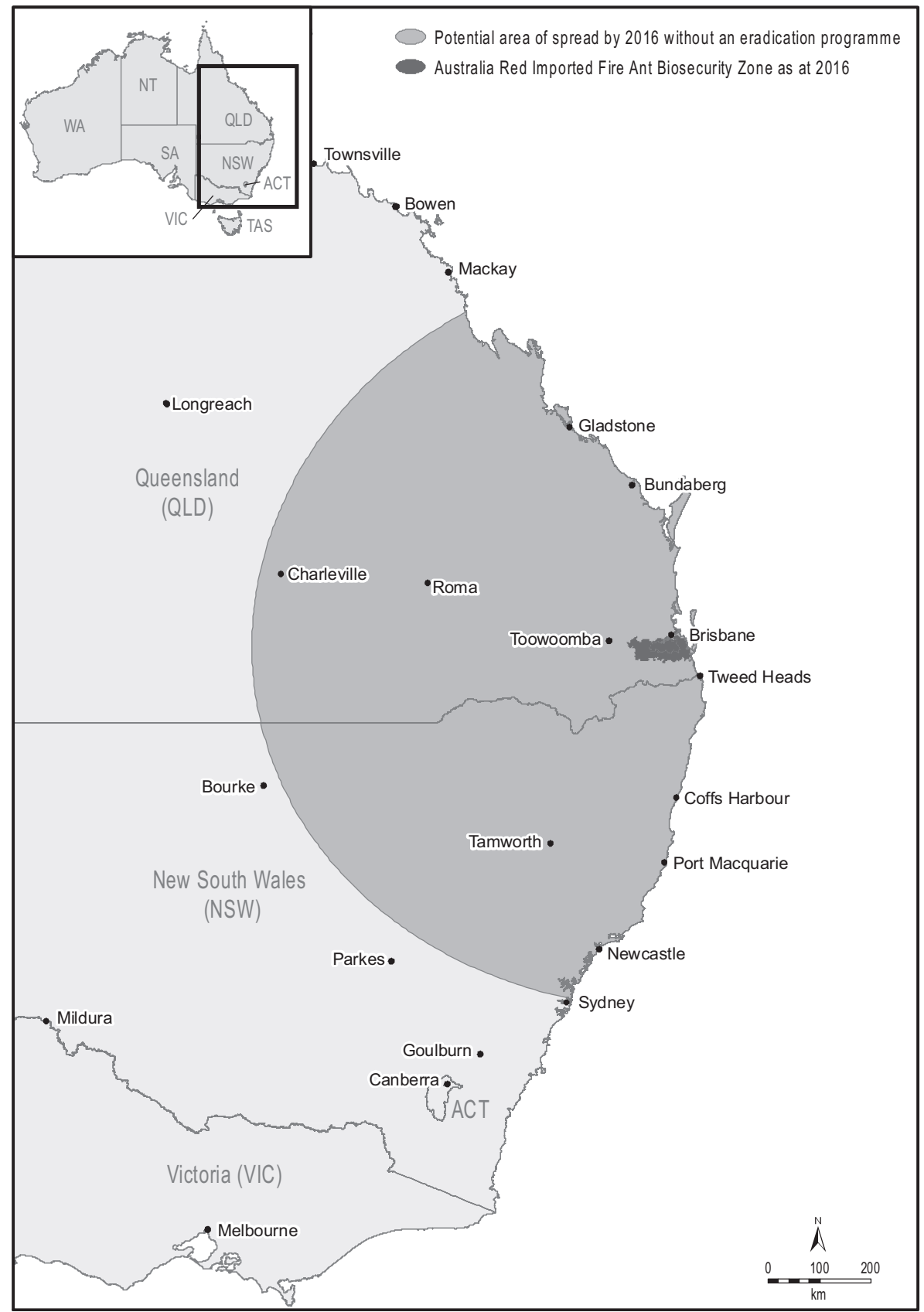

Figure 1. Map showing the current (2016) Red Imported Fire Ant Biosecurity Zone in Queensland and the potential spread of the ant by 2016 if there had been no eradication programme (based on a spread rate of $48 \mathrm{~km} /$ year in Texas).

became established, at between $\$ 8.5$ and \$45 billion (Kompas \& Che 2001; Antony et al. 2009; Hafi et al. 2014). The higher figure takes potential environmental impacts and changed costs into account. Both CLIMEX and Climatch modelling show that most of Australia would be suitable for colonisation, including arid areas with the addition of irrigation (Sutherst
\& Maywald 2005; Bureau of Rural Sciences 2008). In the USA, annual costs for impacts and control in infested areas are \$US7 billion (Avant 2014), in line with estimates by Antony et al. (2009) for Australia when population and sector sizes are taken into account. Despite these figures, since 2008/2009 funding for the programme has been on a year-to-year basis and securing long-term funding has been problematic. The purpose of this article was to raise awareness among government, business and public sectors that Red Imported Fire Ant is not just another invasive, it is a 'super pest' whose impacts, if unchecked, will surpass the combined effects of many of the pests we currently regard as Australia's worst invasive animals (rabbits, foxes, feral pigs, camels, wild dogs, feral cats, cane toads) (see McLeod 2004). Our aim is to highlight some of the potential impacts in Australia in more detail than in previous analyses and provide case examples. We intend to show that the programme has a very broad range of stakeholders and that few sectors will be unscathed should Red Imported Fire Ant not be eradicated or adequately managed.

\section{Methodology}

Impacts of Red Imported Fire Ant in Australia are extrapolated from expenditures and damages experienced currently throughout the southern USA and applied to Australian economic sectors in consideration of the level of local production, sector size and population. Assumptions are that (i) Red Imported Fire Ant will colonise all suitable habitats in Australia identified in climate modelling; (ii) impacts in Australia will be similar to those experienced in the USA; and (iii) governments in Australia have adopted a 'management' approach to the pest; that is, there is no central, coordinated attempt at eradication or containment but quarantine zones may be employed to slow the spread. We have tried to be conservative in estimating likely impacts. For many case examples, detailed costings for impacts described were either not available or not in a form that could be extrapolated to arrive at a full cost for Australia. To illustrate, we could locate data on the average impact cost per head of cattle in the USA but nothing similar for horses or other animals. We acknowledge that some costs may not be realised once the ant has colonised all suitable habitats, for example, the cost of quarantine measures although there may still be export implications. Costs due to native ants which are pests 
of honeybees and some crops have not been considered in this study. The comparative impacts of Red Imported Fire Ant versus native ants are unknown. Generally, the impacts of invasive species are greater given their comparatively greater abundance and aggressiveness in invaded habitats. The largest uncertainties are the rate and degree of colonisation of the ant across suitable habitat in Australia. With natural spread, it may be several decades before the full distribution is realised, or very much sooner with human-assisted movement as in other countries. Our main sources for US impacts are papers published in the 1990s and early 2000s out of Texas A\&M University and remain the most detailed studies available. Reported annual costs in the USA due to this pest have continued to increase since that time.

Data on the size and value of the various Australian economic sectors examined were obtained from the Australian Bureau of Statistics (ABS), Australian Bureau of Agricultural and Resource Economics and Sciences (ABARES), the Rural Industries Research and Development Corporation (RIRDC), Australian Golf Industry Council (AGIC) and Tourism Research Australia. Conversions from USD to AUD are based on published Reserve Bank of Australia rates at the date of the respective journal publication and adjusted for Consumer Price Index (CPI) inflation using the ABS CPI inflation calculator as at March 2016.

\section{Results}

Our analysis shows that if Red Imported Fire Ant was to become widespread in Australia, adverse impacts are likely in most sectors of the economy affecting plant and animal industries, the environment, development, infrastructure, and health and lifestyle. Individual components identified within these sectors include cropping, organic growers, forestry, apiculture, nursery and landscaping, cattle industry, equine industry, poultry industry, aquaculture, pet industry, environment, development and construction, mining industry, infrastructure, human health, schools, public amenities, sport and tourism. Examples of some of the likely impacts for each component are presented below. These are not exhaustive but serve to illustrate the magnitude of the problem faced.

\section{Plant Industries}

\section{Cropping}

More than 50 commercial food crops are reported to be impacted by Red Imported Fire Ant in the USA, including vegetable, melon, fruit, nut, vine and grain crops. All of these crops are grown in Australia. Impacts in the USA include loss of crop yield, plant mortality, damage to equipment and infrastructure, medical expenses, increased labour costs and market access. Examples of damage in some individual crops are provided below.

- Citrus. In surveys of 1- to 4-year-old citrus groves (orange, grapefruit) in Florida, Banks et al. (1991) found that Red Imported Fire Ant built mounds around or near the base of young trees and fed on the bark and cambium to obtain sap, often girdling and killing the tree. They also chewed off new growth at the tips of branches and fed on flowers of developing fruit. Such feeding damage occurred wherever the ant was abundant. Smittle et al. (1988) reported tree mortality in groves in two Florida counties due to girdling of between $12.5 \%$ and $17.2 \%$, while Adams (1986) reported that feeding around the calyx results in a $>50 \%$ decrease in flower maturation and $40 \%$ damage to newly set fruit. Replacement costs in 1988 were estimated at around US\$ 750.00 (or \$A2073.09 in 2016 values) for each hectare of citrus $<4$ years old (Smittle et al. 1988). In 2015, an estimated 2011 ha in Australia contained citrus trees not yet of bearing age (ABS 2015a). Extrapolating the US data to the Australian situation would equate to replacement costs for the industry of A\$2.78 million every 1-2 years.

- Soya beans. Red Imported Fire Ant damages soya bean crops primarily by destroying germinating seeds and seedlings. In experimental plots of soya beans in Gainesville, Florida and
Gulfport, Mississippi, Adams et al. (1983) recorded yield losses of 33\% at Gainesville and 20\% at Gulfport.

- Potatoes. In a commercial potato field in the Hastings area of north-eastern Florida, assessments by Adams et al. (1988) showed a yield loss of $30 \%$ due to feeding by the ant. The damage to the tubers ranged from small external feeding scars to extensive tunnelling throughout the tubers. In addition to the direct loss of potatoes, the severity of damage increased grading time threefold.

- Sunflowers. In a 24-hectare sunflower field in Medina County, Texas, Stewart and Vinson (1991) observed damage about 1 week after the plants emerged. Red Imported Fire Ant chewed on sunflower stems near ground level, removing the succulent outer phloem tissue leaving the woody cortex. Droughtstressed sunflower plants, damaged by the ants' feeding, died. Approximately $40-50 \%$ of the crop was lost to damage.

- Cucumbers. Again in Texas, in Uvalde County, Stewart and Vinson (1991) observed damage in a 20-ha cucumber crop, consisting of furrows or holes in the stems and hypocotyl where the ant removed plant tissue to a distance of $4-5 \mathrm{~cm}$ below ground, destroying $2.4-4 \%$ of seedlings.

- Eggplants. In 1982, a 50\% reduction in yield occurred in a 12-hectare crop of eggplant in Marion County, Florida, due to damage, as the ant fed on new growth, leaves and stem and occasionally girdled the stems (Adams 1983). It was estimated that the farmer would have suffered a US\$55 500 loss on that crop. In current (2016) Australian dollars, this would be equivalent to $\mathrm{A}$ $\$ 186478$.

- Grain crops. Red Imported Fire Ant damages seeds of corn, sorghum and wheat by rasping through the pericarp at the germ portion of seed and removing the embryo. Both dry and germinating seeds are affected (Drees et al. 1991). In Arkansas, a 20\% reduction in yield of grain sorghum has been 
reported; the ant damaged plants by breaking off cotyledons and eating the starch out of the seed (Polk et al. 1999). Arising from their laboratory studies in Texas, Morrison et al. (1997) speculated that if their data are indicative of field conditions then growers might expect from 15\% to 95\% damage to wheat, corn and sorghum seed during periods of low germination associated with soil moisture deficit. In some cases, this may result in complete crop-stand failures (Morrison et al. 1999).

In addition to the direct damage caused to crops, there can also be significant nonyield costs. For example, tree crops and vineyards use hand labour throughout the year for tasks such as pruning, raking and harvesting. In infested fields, crews may not be able to enter because of the ants' aggressive nature and painful stings, or they may request a higher wage to compensate for additional risks (Jetter et al. 2002). Alternatively, producers could treat their fields with insecticides. For crops that are harvested mechanically, mounds may damage harvesters with consequent costs for repairs and downtime. Red Imported Fire Ant can also damage electrical and irrigation equipment, and for some farm products, growers may face compliance costs for safe movement of product outside a quarantine area. For example, in south-east Queensland, as in the USA, restrictions are placed on the movement of hay outside of the declared Red Imported Fire Ant restricted area.

Hay bales provide shelter, temperature regulation and a source of food, and bales left in the field can become infested within 1 day of baling (Weeks et al. 2001). Hay producers within Queensland's restricted area must comply with protocols for the safe harvesting and storage of hay otherwise the product is prohibited from leaving the property. When hay is in good supply, a round bale may sell for A $\$ 30-40 /$ bale and when scarce for A\$100-120/bale. Producers under quarantine or with inadequate storage facilities may be prevented from maximising the price they receive and also face increased costs of production.
For sugar cane and cotton crops, Red Imported Fire Ant can have a beneficial impact in that it preys on pests such as the sugar cane borer Diatrea saccharalis, cotton bollworm Helicoverpa zea and beet armyworm Spodoptera exigua (Brinkley et al. 1991; Diaz et al. 2004; Styrsky \& Eubanks 2010). However, studies by Eubanks (2001) indicate that the ant is also a significant predator of some of the most important biological control agents in these crops. This finding, together with non-yield damage, may negate any benefits.

In Texas, increased annual crop production costs (based on six major crops) due to Red Imported Fire Ant are estimated to be US\$8.95/acre or US\$22.12/ha (A \$53.27 at 2016 values) (Segarra et al. 1999; Gutrich et al. 2007). With more than 6 million ha sown in Australia to the broadacre crops (excluding cotton and sugar), fruit and nuts, and vegetables that are known to be impacted in the USA (ABS 2015a), the cost to these industries could exceed A\$331 million.

Hafi et al. (2015) also highlight the significant losses to cropping industries, estimating that the treatment, expenditure and the residual losses in revenue expected from Red Imported Fire Ant could reduce gross margins by around $10 \%$ in crop farms.

\section{Organic growers}

In Queensland, pesticides used by the programme to treat Red Imported Fire Ant have impacted the certification status of organic growers. Australia's National Standard for Organic and Bio-Dynamic Produce (revised 2015) lists a range of products that are permitted to be used for plant pest control. However, none of these products are yet registered for use against Red Imported Fire Ant in Australia under the Agricultural Pesticides and Veterinary Medicines Authority (APVMA). At present, the bait products used by the programme do not conform with the current materials explicitly allowed under the National Standard because the active ingredients, insect growth regulators pyriproxyfen and $s$ methoprene, are synthetically produced. This means that if they are used to treat organic properties, operators will lose their certification status and will need to apply for re-entry after 12 months. Very few of the products listed as 'organically acceptable' have been tested against Red Imported Fire Ant, a requirement for registration by the APVMA. Those that have been tested in the USA have proved of variable efficacy (Barr \& Best 1999; Oi \& Oi 2006). In Australia, organic certification provides an average increased return for growers of $35 \%$ on sale of produce (Marg Will, Organic Industry Standards Certification Council, pers. comm., 2016).

\section{Apiculture}

Red Imported Fire Ant invades honeybee colonies and robs them of stored honey, pollen, larvae and pupae thus having a devastating impact on the colony. They also compete with bees for nectar from flowers and extra floral nectaries (Vinson 2013). However, the ant does have some positive benefits in predating wax moths and hive beetles which are also pests in colonies. As well, they can act as beneficial scavengers in apiaries by removing dead bees deposited outside colonies that otherwise may act as a reservoir for pathogens or attract pests (Pankiw 2007). In the USA, state and federal quarantines have been imposed on the movement of honeybee colonies as a result of the ants' detection in bee shipments from Texas destined for almond orchards in California (Jetter et al. 2002).

In Texas, where Red Imported Fire Ant is a pest of honeybees, beekeepers spend on average US\$11 (or A\$15.98 in 2016 values) per colony on control measures, primarily insecticides (Pankiw 2007). In 2014, ABARES determined the gross value of production (GVP) of the beekeeping industry in 2012-2013 was A\$88 million (ABARES 2014). There were approximately 12400 registered beekeepers in Australia with about 528000 hives (RIRDC 2015) which would equate to more than A\$8.4 million annual costs to beekeepers based on the Texas figure. No data were available from the Australian Honey Bee Industry Council on current costs of native ants to beekeepers.

\section{Forestry}

The impacts of Red Imported Fire Ant on forestry are likely to be limited (MAF 
2001), as it prefers open sunny areas and is rarely found in mature forests and other areas of heavy shade. However, there may be some impacts at forest edges, in young stands and in forest nurseries. Harvesting and other forestry operations may be affected through damage to electrical equipment, stings to workers and the need for treatment and management measures.

In the USA in 1972, a heavy infestation of pine tortoise scale (Toumeyella parvicornis), attended and protected by Red Imported Fire Ant workers, was observed in a three-year-old slash pine (Pinus elliottii var. elliottii) plantation in Clay County, Florida. At least $50 \%$ of trees in a 40 ha area were affected, resulting in pockets of chlorotic, stunted trees, often covered with sooty mould. Mean height growth was significantly reduced by $40 \%$ in scale-infested trees (Wilkinson \& Chellman 1979). The ant destroyed $11 \%$ of the longleaf pine (Pinus pallustris) seed sown in an ant-infested area near Alexandria, Louisiana, in 1970 , and nearly $33 \%$ in the same area in 1972 (Campbell 1974). Workers are known to wait until the seed is cracked open for emergence of the radicle, and then enter the opening to feed.

\section{Nursery and Iandscaping}

Red Imported Fire Ant is a notorious hitchhiker and is readily transported long distances when articles such as soil, nursery stock, turf and other items are transported outside the infested area. The rapid early spread in the southern USA in the early 1950s was closely linked to shipments of nursery stock (Tschinkel 2006). Federal quarantine provisions were invoked in the USA in 1958 in an effort to slow or prevent the spread (USDA 2013). The regulations mandate specific treatments for nursery stock and other commodities to be shipped out of quarantine areas. Annual treatment costs required to comply with federal quarantine requirements is conservatively estimated at US\$125/acre in Georgia (Sparks et al. 1997) and US \$650/acre in South Carolina (Gorsuch 1998). The total area of nurseries in Australia is 4660 ha (ABS 2015a). Based on these costs (converted to hectares and Australian dollars and adjusted for CPI), the treatment costs for the Australian industry could amount to between A $\$ 3.77$ and A $\$ 16.24$ million. The Nursery and Garden Industry Queensland in 2015 estimated the cost to nursery production in that state at $\mathrm{A} \$ 18$ million per year in mitigation, compliance and lost market costs.

\section{Animal Industries}

Red Imported Fire Ant is known to cause harm to a wide range of livestock and pets including meat and dairy cattle, sheep, goats, pigs, horses, donkeys, poultry, ostriches, cats, dogs and other small animals (Barr \& Drees 1994; Lard et al. 2001). Examples of its impacts on five selected animal industries are provided below.

\section{Cattle industry}

Animals are rarely stung through their fur, and most injuries occur around a cow's muzzle, eyes and exposed skin around the belly and hindquarters (Barr \& Drees 1996). The mucous membranes in the animals' eyes and nostrils are attractive to the ant, and stings cause blindness and swelling, which may cause suffocation. Just the discomfort of stings has been blamed for calf 'set back' that can cost many dollars at sale time (Barr \& Drees 1996). Penned or newborn animals are at greatest risk and multiple stings can occasionally result in death (Riggs \& Drees 2003). Cattle may become malnourished when the ant invades their food and water. In a survey of veterinarians in Texas in 1993, twothirds of all respondents reported having treated animals for Red Imported Fire Ant injury and $\mathbf{1 7 . 5 \%}$ were cattle (Barr \& Drees 1994).

The annual cost to Texas cattle producers (who will need to pay for repairs and replacement costs for equipment and materials, cattle injury and death, losses in hay and insecticide) is estimated to be on average A\$11.24 per head of cattle in current (2016) values (Barr \& Drees 1996; Gutrich et al. 2007). This figure is considered a conservative estimate with other studies having estimated this cost to be up to A $\$ 109$ per head of cattle (Hafi et al. 2014, 2015).

Extrapolating the Texas costs to Australia, the Australian herd size was 27.4 million head of cattle in 2015 (ABS 2015a) and potential annual costs to the industry could total A $\$ 308$ million. This is almost double the annual costs of cattle tick Australia-wide (A $\$ 161$ million in 2015) (Lane et al. 2015). In Queensland, where the herd size was 11.3 million head of cattle in 2015 (ABS), annual costs could be more than A $\$ 127.5$ million. In comparison, wild dogs, a significant industry problem, have been estimated to cost Queensland cattle producers A $\$ 48$ million in today's values (Hewitt 2009).

Hafi et al. (2015) also highlight the significant losses to the cattle industry, estimating that the treatment and expenditure and the residual losses in revenue are expected to reduce gross margins by around $40 \%$ in beef farms.

\section{Equine industry}

As described for cattle above, most stings to horses are to the muzzle, eyes and exposed skin or where fur is thin. Recumbent or newborn animals are at greater risk from stings. Clinical signs of stings include pain, itching and skin irritation. Secondary complications include lameness, respiratory difficulty and abortion (Waldridge 2008). If treatment does not occur promptly, animals can go blind from stings around their eyes, and some horses may develop a severe allergic reaction to being stung (Judd 2009). In a survey of Texas veterinarians in 1993, horses comprised $8.5 \%$ of all animals treated each year for Red Imported Fire Ant stings (Barr \& Drees 1994). Other impacts may occur through interference with hay production, damage to farm equipment, forage degradation, infested feed and reduced feeding (Bambara \& Watson 2008). A study for the RIRDC (Gordon 2001) estimated the contribution of the equine industry to the Australian economy at A $\$ 6.3$ billion a year.

\section{Poultry industry}

Red Imported Fire Ant causes problems on poultry farms by attacking chickens, infesting feed and foraging on broken eggs. Stings can affect the growth and development of young chickens through stress, and birds will not eat infested seed, all of which can result in decreased egg production. In some cases, multiple stings will cause the death of chicks (Pollet 
2006), and blemishes that can reduce the quality of poultry (Tomberlin \& Drees 2007). In Texas, $94 \%$ of poultry operations reported problems with Red Imported Fire Ant (Hall et al. 1999). Given the estimated value of the Australian poultry industry of $\$ 2.6$ billion and the value of Australian egg production of A\$728.8 million (ABS 2015b), this could potentially have a considerable impact on Australian poultry operations.

\section{Aquaculture}

Fish farms are a prime habitat for Red Imported Fire Ant, which constructs mounds on the margins of ponds and on dams and levees. Fish farmers typically work barefoot and in short pants along the pond banks and the probability of being stung is very high (Oi et al. 2004). Most fish farmers are reluctant to use baits or other chemical methods of control because of the risk to fish. There have been anecdotal reports of mass fish mortality due to the ingestion of Red Imported Fire Ant, but studies have failed to confirm this phenomenon (Ferguson 1962; Crance 1965). Contreras and Labay (1999) suggest that, with alates, fish mortality may be due to the digestion of Red Imported Fire Ant toxins rather than physical trauma resulting from stings, and $\mathrm{Hu}$ (2015) adds overindulgence as a possible cause.

\section{Pet industry}

In the USA, small animals and pets are, by far, the most frequently treated type of animal for Red Imported Fire Ant-related health problems. Very young animals, caged animals, or those that are old and have trouble moving, are most likely to be stung (Nester 2014). Skin inflammation and infection are the most common problems, but blindness and death can sometimes result from stings. In a survey of Texas veterinarians in 1993, small animals and pets accounted for more than half of all reported Red Imported Fire Ant injuries but only $16 \%$ of reported animal deaths (Barr \& Drees 1994). The reason for this lower mortality, as compared with cattle deaths which comprised 52\%, may be the time taken for human observation, diagnosis and intervention to prevent mortality.
In the southern USA, it is quite common for the ant to crawl into a pet's feed bowl and sting the pet when it feeds, causing injury and discouraging the animal from using the bowl subsequently (Nester 2014).

\section{Environment}

The environmental impacts of Red Imported Fire Ant in the USA are well documented, affecting wildlife and reducing biodiversity of native plants and animals (Allen et al. 2004). Based on the US experience, Moloney and Vanderwoude (2002) outlined some of the potential impacts in Australia if the pest was to become widely established and these are summarised in Wylie et al. (2016). Lach and Barker (2013) conducted an expanded assessment of the risks in the south-east Queensland bioregion, assessing a total of 123 species comprising 47 birds, 16 mammals, 32 reptiles, 19 amphibians, four freshwater fishes and five invertebrates. They concluded that, among vertebrates assessed, Red Imported Fire Ant is likely to have effects sufficiently severe to cause population declines in $45 \%$ of birds, $38 \%$ of mammals, $69 \%$ of reptiles and $95 \%$ of amphibians.

Birds with terrestrial or low arboreal nests will be impacted directly through predation of eggs or hatching chicks, and indirectly by the reduction in invertebrate densities (food source) that occurs in heavily infested areas (Allen et al. 2004). In Australia, examples of species that may be impacted include Australian brush-turkey (Alectura lathami), beach stone-curlew (Esacus neglectus), bush stone-curlew (Burbinus grallarius), black-breasted button-quail (Turnix melanogaster), little tern (Sterna albifrons), masked lapwing (Vanellus miles) and rainbow bee-eater (Merops ornatus) (Lach \& Barker 2013).

Mammal young that shelter in a terrestrial den, and are unable to protect themselves during the early part of their development, are likely to be at risk during this stage. Iconic Australian species that could be impacted in this way are platypus (Ornithorbynchus anatinus) and shortbeaked echidna (Tachyglossus aculeatus) (Lach \& Barker 2013). Carnivorous marsupials that rely on larger invertebrates as a food source would be affected by a decline in invertebrate densities caused by Red Imported Fire Ant, and in Australia, this could include spotted-tailed quoll (Dasyurus maculatus maculatus). Even koalas (Phascolarctos cinereus), when dispersing on the ground, may be stung.

Red Imported Fire Ant may impact both freshwater and marine turtle populations directly by preying on hatchlings and/or indirectly by stinging hatchlings resulting in reduced weight and survival (Allen $e t$ al. 2001). They may be attracted to turtle nest sites by the mucous and moisture released by the female when eggs are laid (Allen et al. 2001; Dziadzio et al. 2016). Juveniles are vulnerable in the piping and hatchling stages and Allen et al. (2001) recorded $70 \%$ mortality of hatchlings of the freshwater turtle Pseudemys nelsoni in laboratory experiments in Florida. Species at risk in Australia include green turtle (Chelonia mydas), flatback turtle (Natator depressus), hawksbill turtle (Eretmochelys imbricata), leathery turtle (Dermochelys coriacea), loggerhead turtle (Caretta caretta) and Mary River turtle (Elusor macrurus). Mon Repos beach near Bundaberg in central Queensland (approximately $370 \mathrm{~km}$ north of Brisbane) supports the largest concentration of nesting marine sea turtles on the eastern Australian mainland and is one of two largest loggerhead turtle rookeries in the South Pacific Ocean region (Tisdell \& Wilson 2001). The breeding that takes place here is vital for the survival of loggerheads in the region. Turtle watching at Mon Repos is worth around A $\$ 2$ million annually to the local economy (Hamann 2009).

Frog species in Australia likely to be most vulnerable are those that lay their eggs terrestrially under leaf litter or in tunnels in the soil. The ornate burrowing frog (Platyplectrum ornatum) and the superb collared frog/short-footed frog (Cyclorana brevipes) which shelter and aestivate in burrows would be at risk from Red Imported Fire Ant (Lach \& Barker 2013). Many skinks, lizards and snakes are also vulnerable to predation, breeding and foraging may be disrupted, and their prey is likely to be reduced (Lach \& Barker 2013).

Invertebrate communities are likely to be impacted through direct predation, competition for the same resources and 
interference with symbiotic relationships. Beetle, tick, spider and fly populations may be affected along with land molluscs and several vulnerable butterfly species (Moloney \& Vanderwoude 2002). For example, the butterflies Illidge's ant-blue (Acrodipsas illidgei) and pale imperial hairstreak (Jalmenus eubulus) have obligate associations with native ants that are likely to be displaced by Red Imported Fire Ant.

\section{Development}

\section{Development and construction}

Red Imported Fire Ant's preference for open and semi-open habitats including disturbed areas is well known (Tschinkel 2006), and there are many reports linking fire ant occurrence with human development and roads (Stiles \& Jones 1998; Forys et al. 2002). In Brisbane, Australia, an analysis of 1749 sites where fire ant colonies had been detected over the period 20022010 showed that $61 \%$ of sites had experienced some form of major soil disturbance in the previous 1-3 years (BQCC unpublished data). Residential and industrial development and roads accounted for $78 \%$ of this disturbance. Queensland's quarantine requirements prohibit the movement of bulk soil out of declared restricted areas unless with an inspector's approval and the taking of measures to mitigate risk at the expense of the business concerned. Where infestations occur on land being developed for residential or commercial construction, operations may be delayed while appropriate treatment is conducted by the programme. No breakdown of costs is available.

\section{Mining industry}

In the restricted areas in south-east Queensland, numerous businesses involved in the extraction of soil, sand, gravel, stone and coal are impacted by the quarantine regulations on bulk movement of product that may harbour Red Imported Fire Ant. These businesses bear the costs associated with meeting quarantine requirements on infested land which may include delays in operation until the infestation is eradicated from the site and mechanical screening of product before shipment.

\section{Infrastructure}

\section{Main roads}

Red Imported Fire Ant has caused damage to traffic signal control boxes, lighting and surfaced roads, which are damaged when they dig beneath asphalt or concrete, causing potholes and erosion along the edges. A single colony can do hundreds of dollars' worth of damage this way. They also chew through the silicone sealant used to regulate highway surface expansion causing losses totalling about US\$3/ foot of sealant (Adams 1986).

In Florida and North Carolina, the ant undermines bitumen roads leading to the formation of potholes. It costs US\$200/ pothole to repair, and in one study, there was an average of 4 potholes $/ \mathrm{km}$ caused by Red Imported Fire Ant at a cost of US $\$ 800 / \mathrm{km}$ (or A $\$ 1921$ in current (2016) values) (Banks et al. 1990).

For concrete roads, the ant damages the expansion joint sealant which requires a silicon patch at a cost of US\$82-187/ $\mathrm{km}$ (Banks et al. 1990).

Australia has an extensive network of roads with over $356343 \mathrm{~km}$ of paved roads (CIA 2011). Even if say 1\% of these roads were affected in a similar manner to the USA, there would be additional costs of A\$6.84 million to maintain roads Australia-wide.

\section{Telecommunications and electrical supply and equipment}

Red Imported Fire Ant has an affinity to electrical utilities. The accumulation of foragers in electrical equipment is thought to be the result of an individual ant finding and closing electrical contacts, then releasing pheromones that attract other workers to the site (Vander Meer et al. 2002). Arriving ants that touch shocked ants also get shocked. The accumulation of ants around a switching mechanism causes it to malfunction. Another aspect of ant behaviour also causes problems to electrical equipment. Colonies move into utility housing and import soil in which to nest. The result is moisture build-up and corrosion of the housing, a problem frequently associated with malfunctioning transformer units.

Segarra et al. (1999) estimate costs of US\$8.90 (or A\$21.43 in current values) per capita per year for treatment and repair of electrical components by electrical and telecommunication companies. Extrapolated to Australia with its population of over 23.7 million, this would amount to costs to the electrical and telecommunication companies of approximately A\$508 million.

\section{Airports}

Red Imported Fire Ant has been found in airport runway lights, signal control boxes and surfaced runways, which, like roads, are damaged when they dig beneath them, causing potholes and erosion along the edges. Foragers gnaw lighting cables until these short out causing runway lights to be shut off and planes to run off-course, potentially placing lives at risk (Lofgren 1986). The economic impact to airports in the USA is estimated to be over US\$84 million (Lard et al. 2006) (A\$142.93 million in current values).

\section{Health and Lifestyle}

\section{Health}

Unquestionably, the most serious impact of Red Imported Fire Ant was it to become widely established in Australia at densities observed in the USA is the threat to human health. The severity of sting reactions range from a typical local sterile pustule or rash to severe secondary infection or life-threatening anaphylaxis (Solley et al. 2002). A 1988 survey of physicians in the USA resulted in reports of 83 deaths (32 confirmed) attributed to fatal anaphylactic reactions to stings, with victims ranging in age from infancy to 65 years (Rhoades et al. 1989). Most deaths were caused with less than five stings. Taber (2000) puts the toll at 100 deaths and considers that this is likely to be an underestimation. The ant is difficult to avoid in infested areas and stings can be sustained both indoors and outdoors. Many attacks occur in nursing homes resulting in 
litigation and settlements in excess of US \$1million (Oi 2008). Estimates of the number of people that are stung each year vary greatly. DeShazo et al. (2013) cite data which suggest that $50-89 \%$ of people residing in an infested area will be stung each year, while Pereira et al. (2005) put the figures at between 30 and 60\%. Stafford et al. (1989) reported that an attack rate of $30 \%$ is a conservative estimate when differences in survey methodology are taken into account. More than $1 \%$ of people stung are hypersensitive and may seek medical attention (Pereira et al. 2005). The population of Australia is over 23.7 million (ABS 2015c). This means were the ant to spread, approximately 7 million people would be stung and 71100 may require medical attention for stings each year. Hafi et al. (2014) estimate the average cost could potentially be A\$19 per Australian household for medical expenses due to red imported fire ant. With over 6 million households in 2011 (ABS 2011) in Australia, the total cost for medical costs borne by households could be $\mathrm{A} \$ 114$ million.

In Wuchuan in southern China, soon after the Red Imported Fire Ant incursion, a study found that 416 of 4894 people in five villages had been stung (8.5\%) over the period 1999-2004 (Zhang et al. 2007). Four patients (1\%) experienced systemic anaphylaxis. Later surveys over the period 2005-2011 showed that more than one-third of people in infested areas had been stung and again nearly $1 \%$ of victims experienced severe allergic reactions with some deaths recorded as a result (Xu et al. 2012). In Taiwan, several cases of severe reactions to stings have been reported (Chen et al. 2005; Lee et al. 2014).

In Australia, allergic reactions to ant stings have, until now, been caused by native ant species (e.g. jumper and bull ants Myrmecia spp., green-head ant Rbytidoponera metallica, trap-jaw ants Odontomachus spp., cannibal ants Cerapachys spp. and Brachyponera spp.) (Solley et al. 2002). Some deaths due to native ant stings have occurred and McGain and Winkel (2002) identified six ant sting-related fatalities over the period 1980-1999 due mainly to the jumper ant Myrmecia pilosula. Red Imported Fire
Ant venom is unlike that of any other Australian Hymenoptera species and represents a new risk to the Australian population (Solley et al. 2002).

\section{Schools}

Students on playgrounds or athletic fields are the most likely school occupants to encounter Red Imported Fire Ant, but the ant can also enter classrooms (Vail \& Oliver 2010). As well as the danger of stings and possible life-threatening response, the ant can damage electrical equipment such as ground-installed lighting and air conditioning units, and also mowers. In the USA, the risk of children being stung requires schools to treat all grounds and fields, and this accounts for the majority of costs to schools there (Gutrich et al. 2007). In Texas, legislation has been introduced to allow the use of epinephrine auto-injectors at school events for lifethreatening reactions.

In Texas, the average annual costs of treatment, repair and replacement of damaged equipment was estimated at US \$4954/school/year (or A \$14176 in current (2016) values) (Lard et al. 1999). The majority of this expenditure (71\%) was for treatment measures, and it was noted that the grounds at the schools were extensive. It would be expected that if regular treatment was conducted, then the costs of repair and replacement of damaged equipment would be greatly reduced. In 2015, there were 9404 schools in Australia (ABS 2015d). Based on the US impacts, this could mean Australian schools could face additional costs of \$133.3 million each year.

In south-east Queensland, since the start of the programme, Red Imported Fire Ant infestations have been detected and treated at more than 50 schools (BQCC unpublished data).

\section{Defence-Military training}

A survey of US military personnel conducted in 1997 determined the effects of biting and stinging arthropods during operations and training (Mehr et al. 1997). Nearly $70 \%$ of respondents reported experiencing problems attributable to insects such as Red Imported Fire Ant which obstructed movement and field position, prevented concealment and cover, disrupted manoeuvres and caused panic. Twenty per cent of respondents reported attendance at sick call for treatment of bites or stings, and 4\% were hospitalised or assigned to quarters. Fifteen per cent of US military personnel reported fire ant as the most problematic insect forcing soldiers to leave weapons, change or disclose position and abandon a post during military manoeuvres. Red Imported Fire Ant has also been reported as a new hazard to military camps in Taiwan (Chen et al. 2005).

\section{Public amenities and sport}

\section{Public urban areas}

Local government will have increased expenditures for treatment, repair and replacement in infested areas accessed by the public (Gutrich et al. 2007). Areas include parks, recreational areas, public office and building areas, and footpaths. Red Imported Fire Ant costs for five metroplexes in Texas were assessed at US $\$ 36.73 /$ acre or US\$90.76/ha (Lard et al. 1999 cited in Gutrich et al. 2007). When converted to AUD and adjusted for CPI, this is equivalent to A $\$ 218.62 / \mathrm{ha}$.

\section{Cemeteries}

In the southern USA, infestation in cemeteries is common, perhaps due to being attracted to open, grassed and watered areas. Tunnelling by workers can undermine graves and cause the toppling of headstones. Visitors to the cemetery and maintenance staff have been stung. In Texas, annual damages and expenditures in cemeteries were estimated at almost US $\$ 64$ million (Lard et al. 2001). This is equivalent to A $\$ 183.15$ million in current values.

\section{Golf}

Red Imported Fire Ant has made a substantial economic impact on the golf courses of the five large metroplexes of Texas. In 1998, expenditure on treatment, repair, replacement and medical costs was US $\$ 64495$ per golf course and totalled almost US\$30 million for these metroplexes (Lard et al. 1999). One of the most significant 
costs was for replacement of costly automated irrigation systems due to Red Imported Fire Ant habitation in the system.

The Australian golf industry had an annual economic value to the Australian Gross Domestic Product (GDP) of A \$2.7 billion in 2006 and is a major sport industry contributor to the Australian economy (AGIC 2009). There are approximately 23271 holes on golf courses in Australia (Golf Australia 2009). Based on Texas figures of US\$4 003 per hole per year due to Red Imported Fire Ant-related costs (Gutrich et al. 2007), converted to AUD and adjusted for cost of living, we estimate Red Imported Fire Ant will cost Australian golf courses almost A $\$ 224$ million per year.

\section{Sports fields}

In 2013, Red Imported Fire Ant stings led to the death of a 13-year-old student during a football game. This resulted in proactive management programmes being implemented across several Texas school districts and legislation introduced to allow the use of epinephrine auto-injectors at school events for life-threatening reactions (Nester et al. 2015).

In Texas, Red Imported Fire Ant on athletic fields is a constant problem. The Dallas Independent School District employs a team of six pest control technicians to inspect all fields in the district at least every 2-3 weeks during playing seasons and broadcast treat the entire field if there are three or more mounds (Himes 2011).

\section{Auto racing}

Twice a year about 250000 race fans converge on the National Association for Stock Car Auto Racing's fastest track in the USA, Talladega Superspeedway in Alabama - many of these occupying campgrounds for up to a week. The main complaint from race fans was Red Imported Fire Ant. Track officials attempt to rectify the problem by giving small bags of Amdro $^{\circledR}$ (ant bait) to campers who made complaints (Dorough 2006).

\section{Tourism}

Tourism makes an important contribution to the Australian economy. In 2014-2015, the industry contributed A\$107 billion in total visitor expenditure, directly contributed $2.7 \%$ of the national Gross Domestic Product and accounted for $4.6 \%$ of total jobs (Australian Government 2015). There were 6.6 million international visitors and 83.2 million domestic overnight visitors.

Red Imported Fire Ant may impact directly and indirectly on tourism. Hotel and resort areas, for example, would incur at least costs similar to public urban areas (US\$36.73/acre; US\$90.76/ha), for costs of treatment to control ant numbers, and costs to repair or replace damaged property/equipment (Gutrich et al. 2007). There are liability issues if people or pets are hurt. In a study by Tracey et al. (1995), 51\% of 107 previously unexposed subjects were stung within 3 weeks of arrival in an endemic area.

There are also foregone outdoor opportunities for tourists. Beaches are prime sites for human recreation and underpin many coastal communities around the world (Klein et al. 2004). They are important drivers of tourism in Australia. In the USA, the ant is known to establish nests along foreshores and sandy dunes, and forage into the intertidal zone (Defeo et al. 2009). Activities such as picnicking, sunbathing and swimming may be affected on infested beaches. In metroplexes in Texas, $26.8 \%$ of householders have limited their outdoor activities due to Red Imported Fire Ant (Lard et al. 1999).

\section{Discussion}

Our intent in this paper was not the duplication of cost-benefit analyses already conducted, but to explore more fully some of the impacts experienced in other countries where Red Imported Fire Ant is established and to put these into an Australian context. This encompassed not just financial extrapolations, but also consideration of possible impacts on daily life and the environment in this country that are sometimes difficult to capture in dollar terms. For example, while Australians may read about Red Imported Fire Ant attacking marine turtle hatchlings in Florida (Allen et al. 2001), it is confronting to consider that this could actually happen at Mon
Repos in Queensland, the most visited and accessible sea turtle rookery in Australia and the second largest rookery for the endangered loggerhead turtle in the South Pacific Ocean region (Tisdell \& Wilson 2001). Mon Repos is just a few hundred kilometres north of Brisbane, and well within the postulated spread range of the pest had there been no eradication programme (Fig. 1). Potential impacts are on both species survival and ecotourism.

We believe that the assumptions used in this paper, as outlined in the methodology, are credible based on the experience overseas and in Australia. CLIMEX and Climatch modelling indicates that there are few places in Australia where Red Imported Fire Ant could not become established. Initial predictions of the potential spread of the ant in the USA based on climatic limitations, mainly the degree of cold tolerance (Buren et al. 1974), have long been exceeded and the ant can survive in areas with winter snow. It is pushing northward along the east and west coasts of the USA and could well reach Canada (Bennett 2016). In arid regions, Red Imported Fire Ant can colonise anywhere there is a source of water (surface, accessible groundwater or irrigation). The 'tyranny of distance' in Australia is no longer the barrier it once was with modern transportation. Red Imported Fire Ant is a proven hitchhiker and not dependent on transport in identifiable high-risk products. For example, it was detected post-quarantine in a crate of new mining machinery from the USA in Roma, Queensland in 2009 (destined for Western Australia) (Wylie et al. 2016) and in a container of bar fridges from China in 2013 in rural Victoria. The importance of a centralised, coordinated approach to eradication and containment cannot be overstated. In Taiwan and China, responsibility for dealing with the pest was devolved to an assortment of individual departments or agencies, each with their own budget and jurisdiction (Kuo 2008), and eradication attempts have now been largely abandoned in favour of management (Wang et al. 2013). 'Management' is the situation we currently observe in the USA, from which our potential impacts were extrapolated. 
It should be noted that, with the exception of compliance costs on business, we are unable to provide many examples of negative impacts in Australia as these have been largely avoided because of the programme. While a handful of people have sought medical attention for stings in Brisbane, no one has died. Similarly, there have been no recorded deaths or serious injury to livestock or pets, or known major environmental impacts. While there is widespread awareness in south-east Queensland due to effective community engagement, few Queenslanders have actually encountered the ant. Nevertheless, there are signs of what may occur if we fail to eradicate. Several infestations with very high mound densities have been recorded over the life of the programme, for example, an estimated 90000 mounds in a landfill west of Brisbane in 2007 (Wylie et al. 2016), and 32000 mounds on a 70 ha rural property also on Brisbane outskirts in 2010. The latter infestation had built to these numbers in just 5 years following surveillance of the property by the programme in which no Red Imported Fire Ant was detected. At this property, horses were observed to be stung and native ant biodiversity appeared to be reduced (BQCC unpublished data). Several sporting fixtures in Brisbane have been postponed or cancelled following the discovery of mounds on sports fields, and more than 50 schools have had infestations which required restrictions on access to affected areas. Golf courses and parks in Brisbane have been infested, and vegetable growers, hay farmers, extraction industries, airport, sea port and land developers affected by movement controls.

The cost-benefit analysis by Antony et al. (2009) put potential impacts of Red Imported Fire Ant in Australia over 30 years at $\mathrm{A} \$ 45$ billion, which can be averaged at $\mathrm{A} \$ 1.5$ billion/year although this is not linear. We have provided extrapolations of cost impacts in just a few of the case examples where it was possible to do so. Nevertheless, in those few examples, impacts exceed A $\$ 1.65$ billion per annum (crops, including citrus \$A 333780 000; apiculture \$A 8437440 ; nursery and landscaping \$A 18000 000; cattle \$A
307976000 ; roads \$A 6840000 ; telecommunications and electrical supply and equipment \$A 508000 000; health \$A 114000 000; schools \$A 133300 000; golf \$A 224000 000) supporting previous predictions. Eradication in Australia remains technically feasible and cost beneficial by a large margin and warrants the continued support of government, industry and the public.

As noted by eminent Australian biologist and author Tim Low (2015), 'Governments today stress the importance of "intergenerational equity" as they strive to cut spending so future generations aren't shackled with an unfair burden of debt. Biologists have identified another kind of liability: "invasion debt" - the future cost of battling pests that escape today. Australia is still paying dearly for the rabbits and foxes freed more than 150 years ago'. Increased spending on Red Imported Fire Ant is justified to avert that invasion debt and avoid a repeat of history. This is a war that Australia cannot afford to lose.

\section{Acknowledgements}

We are grateful to past and present staff of the Biosecurity Queensland Control Centre who assisted in the collection of data used in this study, in particular Craig Jennings, Heather Leeson, Kimmy Wolfenden, Georgina Lucas, Noel Greiner and Ian Nicolson. We thank George Antony, Director, Industry Analysis, Queensland Department of Agriculture and Fisheries for his assistance and advice on the statistics and for his helpful comments on the manuscript. We also thank Penny Flannigan for preparing the map, Melinda McNaught for her invaluable assistance with editing the manuscript and Ian Gynther for his advice on endangered species. We acknowledge the financial support provided to the National Red Imported Fire Ant Eradication Programme by the Australian Commonwealth, States and Territories.

\section{References}

ABARES (2014) Agricultural Commodities: March Quarter 2014. Australian Bureau of
Agricultural and Resource Economics and Sciences, Department of Agriculture and Water Resources, Canberra.

ABS (2011) Category 3236.0: Household and Family Projections Australia 2011 to 2036. Australian Bureau of Statistics, Canberra.

ABS (2015a) Category 7121.0: Agricultural Commodities, Australia 2014-15. Australian Bureau of Statistics, Canberra.

ABS (2015b) Category 7503.0: Value of Agricultural Commodities Produced, Australia 2014-15. Australian Bureau of Statistics, Canberra.

ABS (2015c) Category 3101.0: Australian Demographic Statistics. Australian Bureau of Statistics, Canberra.

ABS (2015d) Category 4221.0: Schools Australia 2015. Australian Bureau of Statistics, Canberra.

Adams C. T. (1983) Destruction of eggplants in Marion County, Florida by red imported fire ants (Hymenoptera: Formicidae). Florida Entomologist 66, 518-520.

Adams C. T. (1986) Agricultural and medical impact of the imported fire ants. In: Fire Ants and Leaf-Cutting Ants: Biology and Management (eds C. S. Lofgren and R. K. Vander Meer) pp. 48-57. Westview Press, Boulder. CO.

Adams C. T., Banks W. A., Lofgren C. S., Smittle B. J. and Harlan D. P. (1983) Impact of the red imported fire ant, Solenopsis invicta (Hymenoptera: Formicidae), on the growth and yield of soybeans. Journal of Economic Entomology 76, 1129-1132.

Adams C. T., Banks W. A. and Lofgren C. S. (1988) Red imported fire ant (Hymenoptera: Formicidae): correlation of ant density with damage to two cultivars of potatoes (Solanum tuberosum L.). Journal of Economic Entomology 81, 905-909.

AGIC (2009) A snapshot of the Australian Golf Industry: Research Summary Report May 2009. Australian Golf Industry Council, Australia.

Allen C. R., Forys E. A., Rice K. G. and Wojcik D. P. (2001) Effects of fire ants (Hymenoptera: Formicidae) on hatching turtles and prevalence of fire ants on sea turtle nesting beaches in Florida. Florida Entomologist 84 250-253.

Allen C. R., Epperson D. M. and Garmestani A. S. (2004) Red imported fire ant impacts on wildlife: a decade of research. American Midland Naturalist 152, 88-103.

Antony G., Scanlan J., Francis A., Kloessing K. and Nguyen Y. (2009) Revised benefits and costs of eradicating the red imported fire ant. Paper presented at the 53rd annual conference of the Australian Agricultural and Resource Economics Society, 10-13 February 2009. Cairns, Australia.

Australian Government (2015) State of the Industry 2015. Tourism Research Australia, Austrade, Canberra.

Avant S. (2014) On the trail of fire ant pheromones. Agricultural Research 62, 6-7.

Bambara S. B. and Watson W. (2008) Fire ant management in horse operations. Department of Entomology Insect Note, North Carolina Cooperative Extension Service. Available from URL: https://www.ces.ncsu.edu/ depts/ent/notes/forage/fireanthorse.pdf. 
Banks W. A., Adams C. T. and Lofgren C. S. (1990) Damage to North Carolina and Florida highways by red imported fire ants (Hymenoptera: Formicidae). Florida Entomologist $\mathbf{7 3}$ 198-199.

Banks W. A., Adams C. T. and Lofgren C. S. (1991) Damage to young citrus trees by the red imported fire ant (Hymenoptera: Formicidae). Journal of Economic Entomology 84 , 241-246.

Barr C. L. (2002) Yield Loss due to Fire ant Mounds in Hay Harvesting. Texas Imported Fire Ant Research and Management Project. Texas A\&M University, College Station, TX.

Barr C. L. and Best R. L. (1999) Spinosad bait rate and formulation study. Texas Agricultural Extension Service. [Accessed 23 March 2016] Available from URL: www.littlefireants. com/15 spinosad cameron airpark. pdf.

Barr C. L. and Drees B. M. (1994) Results from the Texas veterinarian survey: impact of red imported fire ants on animal health. Proceedings of the 1994 Imported Fire Ant Conference, May 9-11 1994, Mobile, Alabama, USA.

Barr C. L. and Drees B. M. (1996) Texas Cattle Producers Survey: Impact of Red Imported Fire Ants on the Texas Cattle Industry: Final Report. Texas A\&M University, College Station, TX.

Bennett C. (2016) When will fire ant march end? Farm Journal. [Accessed 5 June 2016] Available from URL: http://www.agweb.com/article/where-will-fire-ant-march-end-naa-chrisbennett/.

Brinkley C. K., Ervin R. T. and Sterling W. L. (1991) Potential beneficial impact of red imported fire ant to Texas cotton production. Biological Agriculture \& Horticulture 8, 145 152.

Bureau of Rural Sciences (2008) Climatch v1.0 software. Bureau of Rural Sciences, Department of Agriculture, Fisheries and Forestry, Canberra. [Accessed 14 Mar 2014] Available from URL: http://data.daff.gov.au:8080/Cli match/climatch.jsp.

Buren W. F., Allen G. E., Whitcomb W. H., Lennartz F. E. and Williams R. N. (1974) Zoogeography of the imported fire ants. Journal of the New York Entomological Society $\mathbf{8 2}$, 113-124.

Campbell T. E. (1974) Red imported fire ant, a predator of direct seeded longleaf pine. United States Forest Service Research Note SO-179, pp. 1-3. United States Department of Agriculture, Washington.

Chen Y. F., Chang H. C. and Chao C. M. (2005) Fire ant, a new hazard to military camps in Taiwan. Journal of Medical Science 25, 161166.

CIA (2011) World Factbook. Central Intelligence Agency, Office of Public Affairs, Washington D.C. [Accessed 24 March 2016] Available from URL: https://www.cia.gov/library/pub lications/the-world-factbook/fields/2085.html.

Contreras C. and Labay A. (1999) Rainbow trout kills induced by fire ant ingestion. The Texas Journal of Science 51, 199200

Crance J. H. (1965) Fish kills in Alabama ponds after swarms of the imported fire ant. The Progressive Fish-Culturist 27, 91-94.
Defeo O., McLachlan A., Schoeman D. S. et al. (2009) Threats to sandy beach ecosystems: a review. Estuarine, Coastal and Shelf Science 81, 1-12.

DeShazo R. D., Williams D. F., Goddard J., Rockhold R. and Kemp S. F. (2013) Stings of imported fire ants: clinical manifestations, diagnosis, and treatment. [Accessed 6 May 2016] Available from URL: http://www.uptodate.com/contents/stings-of-imported-fire-antsclinical-manifestations-diagnosis-and-treatment.

Diaz R., Knutson A. and Bernal J. S. (2004) Effect of the red imported fire ant on cotton aphid population density and predation of bollworm and beet armyworm. Journal of Economic Entomology 97, 222-239.

Dorough H. D. (2006) Fire ants at Talladega: bringing NASCAR fans back down to earth. Alabama Cooperative Extension System, Alabama, USA. [Accessed 23 March 2016] Available from URL: http://www.aces.edu/ dept/fireants/documents/TSSArticle.pdf.

Drees B. M., Berger L. A., Cavazos R. and Vinson S. B. (1991) Factors affecting sorghum and corn seed predation by foraging red imported fire ants (Hymenoptera: Formicidae). Journal of Economic Entomology 84, 285-289.

Dziadzio M. C., Long A. K., Smith L. L., Chandler R. B. and Castleberry S. B. (2016) Presence of the red imported fire ant at gopher tortoise nests. Wildlife Society Bulletin 40, 202-206.

Eubanks M. D. (2001) Estimates of the direct and indirect effects of red imported fire ants on biological control in field crops. Biological Control 21, 35-43.

Ferguson D. E. (1962) Fish feeding on imported fire ants. The Journal of Wildlife Management 26, 206-207.

Forys E. A., Allen C. R. and Wojcik D. P. (2002) Influence of the proximity and amount of human development and roads on the occurrence of the red imported fire ant in the lower Florida Keys. Biological Conservation 108. 27-33.

Golf Australia (2009) Golf Industry Report 2009 Final. Golf Australia, Melbourne. Available from URL: http://www.golf.org.au/site/ content/document/00007798-source.pdf.

Gordon J. (2001) The horse industry - contributing to the Australian economy. A report for the Rural Industries Research and Development Corporation, Centre of International Economics, Canberra.

Gorsuch C. S. (1998) Red imported fire ants: impact on South Carolina. Entomology Insect Information Series, Clemson Cooperative Extension, Clemson, USA.

Gutrich J. J., VanGelder E. and Loope L. (2007) Potential economic impact of introduction and spread of the red imported fire ant, Solenopsis invicta, in Hawaii. Environmental Science and Policy 10,685-696.

Hafi A., Spring D., Croft L., Kompas T. and Morey K. (2014) Cost-Effectiveness of Biosecurity Response Options to Red Imported Fire Ants in South East Queensland. Australian Bureau of Agricultural and Resource Economics and Sciences, Department of Agriculture, Canberra.

Hafi A., Addai D., Zhang K. and Gray E. M. (2015) The Value of Australia's Biosecurity System at the Farm Gate: An Analysis of Avoided Trade and on-Farm Impacts. ABARES
Research Report 15.2. Australian Bureau of Agricultural and Resource Economics and Sciences, Department of Agriculture, Canberra.

Hall K. D., Holloway R. L., Carey J. B. and Hoelscher C. E. (1999) Texas Poultry PestControl Practices. Texas Agricultural Extension Service, Texas A\&M University, College Station, TX.

Hamann M. (2009) Creating community collaborations. Marine Turtle Newsletter 123, 1-2.

Hewitt L. (2009) Major economic costs associated with wild dogs in the Queensland grazing industry. Blueprint for the Bush, Queensland State Government, Brisbane.

Himes S. (2011) Fighting fire ants in sports turf. [Accessed 7 June 2016] Available from URL: http://sturf.lib.msu.edu/article/ 2011 aug20.pdf.

Hoffmann B., Luque G. M., Bellard C., Holmes N. D. and Donlan C. J. (2016) Improving invasive ant eradication as a conservation tool: a review. Biological Conservation 198, $37-49$.

Holway D. A., Lach L., Suarez A. V., Tsutsui N. D. and Case T. J. (2002) The causes and consequences of ant invasions. Annual Review of Ecology and Systematics 33, 181-233.

Hu X. P. (2015) An overview of fire ants impact on fish. Imported Fire Ant Conference Proceedings April 6-8, 2015. New Orleans, USA. Available from URL: https://articles.extension.org/sites/default/files/2015\%20Conference $\% 20$ Proceedings 0 . pdf.

Hung A. C. F. and Vinson S. B. (1978) Factors affecting the distribution of fire ants in Texas (Myrmicinae: Formicidae). Southwestern Naturalist 23, 205-213.

Jetter K. M., Hamilton J. and Klotz J. H. (2002) Red imported fire ants threaten agriculture, wildlife and homes. California Agriculture 56. 26-34.

Judd B. (2009) Fire ants in horse pastures. Texas Farm Bureau Network. [Accessed 26 May 2016] Available from URL: http://www.vet erinarypartner.com/Content.plx? $P=A \& A=2920$.

Klein Y. L., Osleeb J. P. and Viola M. R. (2004) Tourism-generated earnings in the coastal zone: a regional analysis. Journal of Coastal Research 20, 1080-1088.

Kompas T. and Che N. (2001) An economic assessment of the costs of red imported fire ant in Australia. Consultancy Report. Australian Bureau of Agricultural and Resource Economics and Sciences, Department of Agriculture, Canberra.

Kuo K.-C. (2008) Management of red invasive fire ants and fruit flies: the Taiwan Experience. Extension Bulletin, Food and Fertilizer Technology Center for the Asian and Pacific Region. [Accessed 6 June 2016] Available from URL: http://www.fftc.agnet.org/htmlarea file/library/20110712175158/eb615.pdf.

Lach L. and Barker G. (2013) Assessing the effectiveness of tramp ant projects to reduce impacts on biodiversity. A report prepared for the Australian Government Department of Sustainability, Environment, Water, Population and Communities, Canberra.

Lane J., Jubb T., Shepherd R., Webb-Ware J. and Fordyce G. (2015) Priority list of endemic diseases for the red meat industries. Final 
Report. B.AHE.0010, Meat and Livestock Australia.

Lard C. F., Hall C., Salin V., Vinson B., Cleere K. H. and Purswell S. (1999) The economic impact of the red imported fire ant on the homescape, landscape and the urbanscape of selected metroplexes of Texas: a part of the Texas fire ant initiative 1997-1999. Fire Ant Economic Research Report \#99-08. Department of Agricultural Economics, Texas A\&M University, College Station, Texas.

Lard C. F., Ellis J., Salin V. and Willis D. B. (2001) The statewide economic impact of the imported fire ant on the economy of Texas - with special emphasis on the urban areas and crop and livestock sector. Texas Imported Fire Ant Research and Management Project, Texas A\&M University, College Station, Texas.

Lard C. F., Schmidt J., Morris B., Estes L., Ryan C. and Bergquist D. (2006) An Economic Impact of Imported Fire Ants in the United States of America. Texas A\&M University, College Station, TX.

Lee Y. C., Wang J. S., Shiang J. C. et al. (2014) Haemolytic uremic syndrome following fire ant bites. BioMed Central Nephrology 15, 5.

Lofgren C. S. (1986) The economic importance and control of imported fire ants in the United States. In: Economic Impact and Control of Social Insects (ed. S. B. Vinson), pp. 227256. Praeger, New York.

Low T. (2015) Red imported fire ants, electric ants, yellow crazy ants: will they take over Australia? The Australian, 2 May 2015. [Accessed 8 June 2016] Available from URL: http://www.theaustralian.com.au/life/ weekend-australian-magazine/red-importedfire-ants-electric-ants-yellow-crazy-ants-willthey-take-over-australia/news-story/5fc713f 7 bbe45462cd79f60783596f27.

Lowe S., Browne M., Boudjelas S. and De Poorter M. (2000) 100 of the World's Worst Invasive Alien Species: A selection from the Global Invasive Species Database. Published by The Invasive Species Specialist Group. [Accessed 05 August 2015] Available from URL: $\quad$ http://www.issg.org/pdf/publications/worst 100/english_100_worst.pdf.

Lu Y. Y., Liang $\bar{G}$. W. and Zeng L. (2008) Study on expansion pattern of red imported fire ant Solenopsis invicta Buren, in South China. Scientia Agricultura Sinica 41, 1053-1063.

MAF (2001) The Potential Economic Impacts of the red Imported Fire ant in New Zealand. Ministry of Agriculture and Forestry, Wellington.

McGain F. and Winkel K. D. (2002) Ant sting mortality in Australia. Toxicon 40, 1095-1100.

McGlynn T. P. (1999) The worldwide transfer of ants: geographical distribution and ecological invasions. Journal of Biogeography 26 , 535-548.

McLeod R. (2004) Counting the Cost: Impact of Invasive Animals in Australia 2004. Cooperative Research Centre for Pest Animal Control, Canberra

Mehr Z. A., Rutledge L. C., Echano N. M. and Gupta R. K. (1997) Army soldiers' perceptions of arthropod pests and their effects on military missions. Military Medicine $\mathbf{1 6 2}$, 804-807.
Moloney S. and Vanderwoude C. (2002) Red imported fire ants: a threat to eastern Australia's wildlife. Ecological Management and Restoration 3, 167-175.

Morrison J. E., Williams D. F., Oi D. H. and Potter K. N. (1997) Damage to dry crop seed by red imported fire ant (Hymenoptera: Formicidae). Journal of Economic Entomology 90, 218222.

Morrison J. E., Williams D. F. and Oi D. H. (1999) Effect of crop seed water content on the rate of seed damage by red imported fire ants (Hymenoptera: Formicidae). Journal of Economic Entomology 92, 215-219.

Nester P. R. (2014) Fire ant control methods around pets. Texas A\&M AgriLife Extension. Fact Sheet ENTO-014. Texas A\&M University, College Station, Texas.

Nester P. R., Hurley J. A., Bostian B. and Terry W. (2015) Tackling fire ants, after a student death, a case study for school IPM in Texas. Imported Fire Ant Conference Proceedings April 6-8, New Orleans, USA. Available from URL: https://articles.extension.org/sites/ default/files/2015\%20Conference\%20Proceedings $0 . p d f$.

Oi D. H. (2008) Pharaoh ants and fire ants. In: Public Health Significance of Urban Pests (eds X. Bonnefoy, H. Kampen and K. Seeney) pp. 175-208. World Health Organisation, Regional Office for Europe, Copenhagen.

Oi D. H. and Oi F. M. (2006) Speed of efficacy and delayed toxicity characteristics of fast-acting fire ant (Hymenoptera: Formicidae) baits. Journal of Economic Entomology 99, 1739 1748.

Oi D. H., Watson C. A. and Williams D. F. (2004) Monitoring and management of red imported fire ants in a tropical fish farm. The Florida Entomologist 87, 522-527.

Pankiw T. (2007) Fire ants: the honey bee's friend and foe. FY 2006-2007 Report on Progress, Texas Imported Fire Ant Research and Management Project. Texas A\&M University, College Station, Texas.

Pereira R. M., Williams D. F., Davis T. S. et al. (2005) Imported fire ants and their management. Proceedings of the 1st Quail Management Shortcourse, p. 49-67. Arcadia, Florida.

Polk W., Teal S. and Segarra E. (1999) Spatial economic impacts of the red imported fire ant on major agricultural crops in Texas. Technical Research Report No. T-1-507, College of Agricultural Sciences and Natural Resources, Texas Tech University, Texas.

Pollet D. K. (2006) Fire ant management in poultry houses. Proceedings of the Red Imported Fire Ant Conference, March 28-30, 2006, Mobile, Alabama, USA.

Rhoades R. B., Stafford C. T. and James F. K. (1989) Survey of fatal anaphylactic reactions to imported fire ant stings. Report of the Fire Ant Subcommittee of the American Academy of Allergy and Immunology. Journal of Allergy and Clinical Immunology 4, 159-162.

Riggs N. L. and Drees B. M. (2003). Protecting penned animals from fire ants. Fire ant plan fact sheet \#43. Texas Cooperative extension. Texas Imported Fire Ant Research and Management Project, Texas A\&M University, College Station, Texas.

RIRDC (2015) Honey bee and pollination program five year research, development and extension plan 2014/15-2018/19. Rural Industries Research and Development Corporation, Australian Government, Canberra.

Segarra S., Teal S., Moates K., Polk W. and Coates C. (1999) Economic impacts of the red imported fire ant in Texas: the search for economically feasible solutions. Final Report 1977-1999. Department of Agriculture and Applied Economics, Texas Tech University, Lubbock, Texas.

Smittle B. J., Adams C. T., Banks W. A. and Lofgren C. S. (1988) Red imported fire ants: feeding on radiolabeled citrus trees. Journal of Economic Entomology 81, 1019-1021.

Solley G. O., Vanderwoude C. and Knight G. K. (2002) Anaphylaxis due to red imported fire ant sting. Medical Journal of Australia 176, 521-523.

Sparks B. L., Hudson W., Ruberson J. and Ross K. G. (1997) VII. Fire Ants. In: Summary of Losses from Insect Damage and Costs of Control in Georgia - 1997, The University of Georgia, Athens, USA [Accessed 23 March 2016]. Available from URL: http://www. bugwood.org/s197/fireants97.htm.

Stafford C. T., Hoffman D. R. and Rhoades R. B. (1989) Allergy to imported fire ants. Southern Medical Journal 82, 1520-1527.

Stewart J. W. and Vinson S. B. (1991) Red imported fire ant damage to commercial cucumber and sunflower plants. Southwestern Entomologist Scientific Note 16, 168-170.

Stiles J. H. and Jones R. H. (1998) Distribution of the red imported fire ant, Solenopsis invicta, in road and powerline habitats. Landscape Ecology 13, 335-346.

Styrsky J. D. and Eubanks M. (2010) A facultative mutualism between aphids and an invasive ant increases plant reproduction. Ecological Entomology 35, 190-199.

Sutherst R. W. and Maywald G. (2005) A climate model of the Red Imported Fire Ant, Solenopsis invicta Buren (Hymenoptera: Formicidae): implications for invasion of new regions, particularly Oceania. Environmental Entomology 34, 317-335.

Taber S. W. (2000). Fire Ants. Texas A\&M University Press, College Station, TX.

Tisdell C. and Wilson C. (2001) Wildlife-based tourism and increased support for nature conservation financially and otherwise: evidence from sea turtle ecotourism at Mon Repos. Tourism Economics 7, 233-249.

Tomberlin J. K. and Drees B. (2007) Poultry pest management. Texas Agricultural Extension Service, Texas A\&M University, Texas. Available from URL: http://oaktrust.library. tamu.edu/handle/1969.1/87136.

Tracey J. M., Demain J. G., Quinn J. M., Hoffman D. R., Goetz D. W. and Freeman T. M. (1995) The natural history of exposure to the imported fire ant (Solenopsis invicta). Journal of Allergy and Clinical Immunology 95 , 824-828.

Tschinkel W. R. (2006) The Fire Ants. Belknap/ Harvard University Press, Cambridge.

USDA (2013) Imported fire ant: quarantine treatments for nursery stock, grass sod, and related materials. Animal and Plant Health Inspection Service, United States Department of Agriculture, Washington.

Vail K. M. and Oliver J. (2010) Managing fire ants in and around Tennessee's schools. 
The University of Tennessee Extension publication \#1788. Available from URL: https:// utextension.tennessee.edu/publications/Documents/PB1788.pdf.

Vander Meer R. K., Slowik T. J. and Thorvilson H. G. (2002) Semiochemicals released by electrically stimulated red imported fire ants, Solenopsis invicta. Journal of Chemical Ecology 28, 2585-2600.

Vinson S. B. (2013) Impact of the invasion of the imported fire ant. Insect Science 20, 439 455.

Waldridge B. (2008) Fire ants and horses. Equine Disease Quarterly article \#11636. [Accessed 02 June 2016] Available from URL: http:// www.thehorse.com/articles/20879/fire-antsand-horses.

Wang L., Lu Y., Xu Y. and Zeng L. (2013) The current status of research on Solenopsis invicta Buren (Hymenoptera: Formicidae) in Mainland China. Asian Myrmecology 5, 125-137.

Weeks R. D., Heimer M. E., Barr C. L. and Drees B. M. (2001) Evaluation of potential imported fire ant quarantine treatments for hay bales. Proceedings of the 2001 Annual Imported Fire Ant Research Conference, 28 February-2 March 2001, San Antonio, Texas, USA.

Wilkinson R. C. and Chellman C. W. (1979) Toumeyella scale, red imported fire ant, reduce slash pine growth. Florida Entomologist 62 71-72.

Wylie F. R., Jennings C., McNaught M. K., Oakey J. and Harris E. J. (2016) Eradication of two incursions of the red imported fire ant in Queensland, Australia. Journal of Ecological Management \& Restoration 17, 22-32.

Xu Y., Huang J., Zhou A. and Zeng L. (2012) Prevalence of Solenopsis invicta (Hymenoptera: Formicidae) venom allergic reactions in mainland China. Florida Entomologist 95, 961-965.

Zhang R., Li Y., Liu N. and Porter S. D. (2007) An overview of the red imported fire ant (Hymenoptera: Formicidae) in mainland China. Florida Entomologist 90, 723-731. 